\title{
COMPARATIVE ANALYSIS OF MORPHOLOGY AND PHYTOCHEMICAL CONSTITUENTS IN DIFFERENT POPULATIONS AND MORPHOTYPES OF DATURA INNOXIA MILL. AND DATURA METEL L. FROM PUNJAB PLAINS
}

\author{
MAHINDER PARTAP, RAGHBIR CHAND GUPTA, SAROJ KUMAR PRADHAN* \\ Department of Botany, Punjabi University, Patiala, Punjab, India. Email: pradhan_sarojkumar@yahoo.com \\ Received: 11 June 2018, Revised and Accepted: 14 September 2018
}

ABSTRACT

Objective: Comparative analysis of morphology and phytochemical constituents in different populations and morphotypes of Datura innoxia Mill. and Datura metel L. from Punjab plains.

Methods: Morphological analyses of different populations have been done. Methanol extracts of seeds and roots of different populations have been prepared and total phenols, flavonoid contents were measured through spectrophotometry. Antioxidant activity was studied by 2, 2-diphenyl-1picrylhydrazyl radical scavenging activity and total antioxidant capacity. Two major compounds, caffeic acid and chlorogenic acid were quantified by high-performance thin-layer chromatography (HPTLC) analyses.

Results: Two morphotypes of $D$. metel were reported in the present study. Out of five different populations of $D$. metel and $D$. innoxia, the wild populations have more bioactive compound as compared to the cultivated ones from the detailed phytochemical investigation. Pharmacologically important two marker compounds chlorogenic acid and caffeic acid has been identified and quantified by HPTLC technique.

Conclusion: Variation in terms of morphology and secondary metabolites exists among the different populations of Datura spp. Among the two plant parts studied, seeds have the maximum amount of bioactive metabolites and antioxidant activity. This study revealed that chlorogenic acid and caffeic acid are the potential polyphenolic compounds in Datura spp. It has been found that the antioxidant activity of plant is due to its polyphenol contents, which provides insight to various researchers to work on it as it imparts health benefit.

Keywords: Datura metel, Datura innoxia, Morphotype, Phytochemical analysis, High-performance thin-layer chromatography.

(C) 2019 The Authors. Published by Innovare Academic Sciences Pvt Ltd. This is an open access article under the CC BY license (http://creativecommons. org/licenses/by/4. 0/) DOI: http://dx.doi.org/10.22159/ajpcr.2019.v12i1.27720

\section{INTRODUCTION}

The word Datura comes from Sanskrit Dustura or Dahatura [1]. Datura is a genus of nine species, poisonous vespertine flowering plants belonging to the family Solanaceae [2]. They are also known as devil's trumpets. Three invasive species grows naturally in Punjab: Datura metel, Datura Innoxia, and Datura stramonium [3]. There is a lot of variability in the morphology of Datura species, i.e., leaf shape, flower and stem color, and seed morphology, which forms the basis of the determination of various morphotypes. There is a lot of variability in the morphological characters of many medicinal plants, and these morphotypes have also variation in their bioactive compounds. Plant morphology is useful in the visual identification of plants [4]. The phenotypic and genetic variation in plants leads to the variation of bioactive components both within the species as well as between the species. The typical bioactive compounds in plants are produced as secondary metabolites. All Datura plants contain tropane alkaloids (scopolamine, hyoscyamine, and atropine), primarily in their seeds and flowers. Due to the presence of these substances, Datura has been used for centuries in some cultures as a poison. D. metel remains a hallucinogenic plant of great enthanopharmacological significance especially in India, Southeast Asia, and Africa. In traditional medicine, it is used to treat chronic bronchitis, seizures, asthma, coma, etc.

The phytochemical techniques are mostly used for the quality control of herbal/Ayurvedic formulations, mainly composed of various chemical components, such as alkaloids, volatiles, saponins, flavonoids, anthraquinones, phenols, tannins, and terpenoids $[5,6]$. Caffeic acid is a phenolic organic compound that is classified as a hydroxycinnamic acid. It's found in all plants as a result of it acts as a key intermediate in the biosynthesis of lignin, one of the principal components of plant biomass and its residues [7]. Caffeic acid has been reported as antioxidant in vitro and also in vivo studies [8]. Chlorogenic acid has been studied as a possible chemical sensitizer involved in respiratory allergy to certain plant materials. As there is scanty data available on the comparative analysis of morphology and phytochemistry of different morphotypes of Datura spp.; therefore, the present study has been undertaken.

\section{METHODS}

\section{Plant material}

The fresh plant materials were collected from a different area of Punjab during August 2016 (Table 1). The botanical identity of the plant was confirmed by comparing with the herbarium specimens. A voucher specimen with accession number has been deposited at the Herbarium of Botany Department, Punjabi University, Patiala. All the reagent and chemicals were procured from HiMedia of analytic grade.

\section{Studies of morphological features}

Morphological features cover the plant height, leaf color and texture, flower color, shape of flower, leaf margin, flower length, spines, stem color and texture, etc. These parameters were studied to gain data regarding morphological features.

\section{Plant material and preparation of extracts}

In the present study, the seeds and roots of different populations of Datura spp. were collected from different parts of the study area for the phytochemical analysis. The collection details of plant materials are mentioned in Table 1. The collected plants were air dried, powdered in grinder, and stored at room temperature. The powdered seeds and roots of each sample $1 \mathrm{~g}$ dissolved in $100 \mathrm{~mL}$ of aqueous, butanol, chloroform, ethyl acetate, hexane, and methanol for overnight. The extract was concentrated and dried using rotary evaporator under 
reduced pressure. The dried extract was re-dissolved in $5 \mathrm{ml}$ of methanol and stored at $4^{\circ} \mathrm{C}$ until further analysis.

\section{Preliminary phytochemical screening}

Each extract was subjected to various phytochemical screening to detect the presence or absence of different types of constituents present in it. Different tests were performed for various constituents, namely alkaloids (Mayer's test), flavonoids (lead acetate test), phenols (acetic acid), and steroids and triterpenoids (Liebermann-Burchard test).

\section{Total phenols content}

Total phenol content in the leaf, stem, and root extracts was determined using Folin-Ciocalteu's reagent [9]. $300 \mu \mathrm{L}$ of extract solution was mixed with $1.5 \mathrm{ml}$ of Folin-Ciocalteu reagent (1 FC: 9 Water). After $10 \mathrm{~min}, 1.2 \mathrm{ml}$ of $2.5 \% \mathrm{Na}_{2} \mathrm{CO}_{3}$ solution was added, and the mixture was allowed to stand for $1 \mathrm{~h}$. The absorbance was taken at $765 \mathrm{~nm}$ using Shimadzu ultraviolet (UV)-visible spectrophotometer. Total phenolic content was expressed as $\mathrm{mg} / \mathrm{g}$ chlorogenic acid equivalents using the linear regression equation of calibration curve.

\section{Total flavonoids content}

The total flavonoid content of leaf, stem, and root extracts was determined by the method of with slight modifications [10]. $300 \mu \mathrm{L}$ of the extract was mixed with $150 \mu \mathrm{L}$ of $\mathrm{NaNO}_{2} 0.5 \mathrm{M}$ and $\mathrm{AlCl}_{3}(0.3 \mathrm{M})$. After $10 \mathrm{~min}, 1.5 \mathrm{ml}$ of $\mathrm{NaOH}(1 \mathrm{M})$ was added. The mixture was mixed thoroughly, and absorbance was taken at $506 \mathrm{~nm}$. The total flavonoid content was expressed as $\mathrm{mg} / \mathrm{g}$ quercetin equivalents using the linear regression equation of the calibration curve.

\section{Total antioxidant capacity (TAC)}

The TAC of stem and root extracts was determined by the phosphomolybdenum assay [11]. $300 \mu \mathrm{l}$ of the extract was mixed with $2.7 \mathrm{ml}$ phospho molybdenum reagent $(28 \mathrm{mM}$ sodium phosphate and $4 \mathrm{mM}$ ammonium molybdate in $0.6 \mathrm{M}$ sulfuric acid). The reaction mixture was incubated in a water bath at $95^{\circ} \mathrm{C}$ for $90 \mathrm{~min}$. After cooling of the mixture to room temperature, the absorbance was taken at $695 \mathrm{~nm}$. TAC results were expressed as ascorbic acid (AA) equivalents (mg AA/g of dry sample).

\section{2, 2-Diphenyl-1-picrylhydrazyl (DPPH) radical scavenging activity} DPPH radical scavenging activity was studied by the method of Otang et al. [12]. A stock solution of DPPH was prepared by dissolving $20 \mathrm{mg}$ in $500 \mathrm{ml}$ of methanol and then stored at $10^{\circ} \mathrm{C}$ until required. Different concentrations $(10-100 \mu \mathrm{g} / \mathrm{ml})$ of each extract were prepared and to this equal volume of a methanolic solution of DPPH were added. The mixture was allowed to stand idle in the dark for $30 \mathrm{~min}$. The absorbance of the mixture was taken at $518 \mathrm{~nm}$. AA was used as a standard control. $\mathrm{IC}_{50}$ value of each extract and standard was calculated, which shows the concentration of sample required to scavenge $50 \%$ of DPPH free radicals.

\section{High-performance thin-layer chromatography (HPTLC)} instrumentation and conditions

Concentrations range from 200 to $600 \mathrm{ng}$ of standard solutions was spotted on silica gel $60 \mathrm{~F}_{254}$ HPTLC plate (Merck, India) in triplicate using CAMAG Linomat V automatic spotter (Dosage speed: $150 \mathrm{~nL} / \mathrm{s}$, Syringe size: 100 $\mu \mathrm{L}$, Band length: $6.0 \mathrm{~mm}$, and Distance between tracks $10.0 \mathrm{~mm}$ ). Plates were developed in a twin-through chamber $(20 \mathrm{~cm} \times 10 \mathrm{~cm})$ to a distance of up to $8 \mathrm{~cm}$ using mobile phase as previously reported by Pradhan et al. [13]. After development, plates were air dried and scanned densitometric at $366 \mathrm{~nm}$ using CAMAG TLC Scanner IV. Peak areas were recorded, and calibration curve of standards was obtained. $8 \mu \mathrm{L}$ of methanol extracts were applied on HPTLC plates using the above-said conditions with both standard solutions. The plates were scanned at $366 \mathrm{~nm}$ and peak area, peak height, and absorption spectra were recorded.

\section{Statistical analysis}

All the data presented were performed in triplicates. The values are mean with standard error.

\section{RESULTS}

The present study is divided into two main categories, i.e. morphological studies and phytoconstituent analysis of different populations of D. metel and D. innoxia.

\section{Morphological analysis}

Two morphotypes of D. metel on the basis of morphological character such as number of whorls of corolla, flower color, and leaf margins are compared in Fig. 1. The data regarding morphological characters of different populations of Datura spp. are given in Table 2.

\section{Preliminary phytochemical screening}

Phytochemical evaluation is one of the important tools for quality assessment which includes preliminary phytochemical screening, chemo profiling, and marker compound analysis. In the present study,
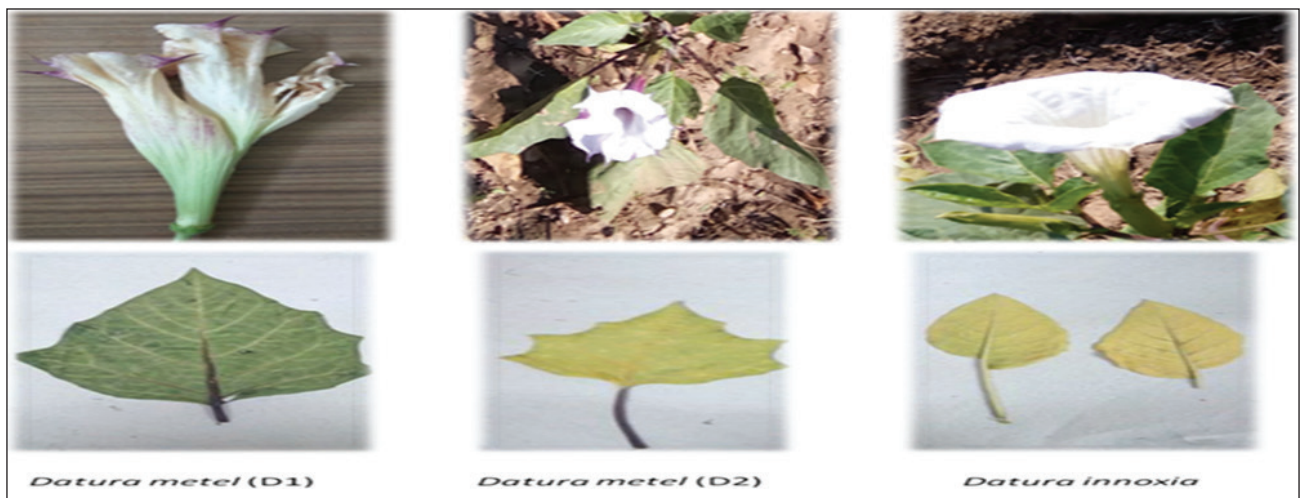

Fig. 1: The morphology of flower and leaf of Datura spp.

Table 1: Plant materials collected from different localities, sample codes, accession number, and altitude

\begin{tabular}{|c|c|c|c|c|c|}
\hline S. No. & Species & Sample code & Localities & Accession number & Altitude (m) \\
\hline \multirow[t]{2}{*}{1.} & D. metel & D1 & Punjabi Bagh, Patiala & 61077 & 255 \\
\hline & & D2 & Plant Conservatory (PUP) & 61034 & 255 \\
\hline \multirow[t]{3}{*}{2.} & D. innoxia & D3 & Plant Conservatory (PUP) & 61033 & 255 \\
\hline & & D4 & Water supply, Abohar & 61032 & 180 \\
\hline & & D5 & Sekhupur, Patiala & 61031 & 255 \\
\hline
\end{tabular}

D. metel: Datura metel, D. innoxia: Datura innoxia 
Table 2: The comparative morphological characters of different populations of Datura spp.

\begin{tabular}{|c|c|c|c|c|c|c|}
\hline \multirow[t]{2}{*}{ S. No. } & \multirow[t]{2}{*}{ Plant characters } & \multicolumn{2}{|l|}{ D. metel } & \multicolumn{3}{|l|}{ D. innoxia } \\
\hline & & D1 & D2 & D3 & D4 & D5 \\
\hline 1. & Average plant height $(\mathrm{cm})$ & 128 & 92 & 65 & 95 & 89 \\
\hline \multirow[t]{3}{*}{2.} & Leaf color & & & & & \\
\hline & Upper surface & Dark green & Dark green & Dark green & Dark green & Dark green \\
\hline & Lower surface & Purple greenish & Purple greenish & Light green & Light green & Light green \\
\hline 3. & Average number of leaves/branch & 24 & 20 & 16 & 23 & 21 \\
\hline 4. & Leaf margins & Serrate & Serrate & $\begin{array}{l}\text { Elliptical entire } \\
\text { margin }\end{array}$ & $\begin{array}{l}\text { Elliptical entire } \\
\text { margin }\end{array}$ & $\begin{array}{l}\text { Elliptical } \\
\text { entire margin }\end{array}$ \\
\hline 5. & Stem (color and texture) & $\begin{array}{l}\text { Violet } \\
\text { non-hairy }\end{array}$ & $\begin{array}{l}\text { Violet } \\
\text { non-hairy }\end{array}$ & $\begin{array}{l}\text { Creamish } \\
\text { green, hairy }\end{array}$ & $\begin{array}{l}\text { Creamish green, } \\
\text { hairy }\end{array}$ & $\begin{array}{l}\text { Creamish } \\
\text { green, hairy }\end{array}$ \\
\hline 6. & Flower color & $\begin{array}{l}\text { Yellowish with } \\
\text { purplish margin }\end{array}$ & $\begin{array}{l}\text { White inside and } \\
\text { purple outside }\end{array}$ & White & White & White \\
\hline 7. & Average flower length & 18 & 17 & 15 & 16 & 16 \\
\hline 8. & Number of whorls of corolla & Three & One & One & One & One \\
\hline 9. & $\begin{array}{l}\text { Average size of fruit (capsule) with } \\
\text { calyx cap }(\mathrm{cm})\end{array}$ & 3 & 2.8 & 2.6 & 2.9 & 2.8 \\
\hline 10. & Average spine length $(\mathrm{cm})$ & 0.7 & 0.6 & 0.5 & 0.6 & 0.7 \\
\hline 11. & $\begin{array}{l}\text { Average number of seed/ } \\
\text { capsule (mature) }\end{array}$ & 49 & 43 & 36 & 48 & 45 \\
\hline 12. & Color of seed (young capsule) & White to pale yellow & White to pale yellow & White & White & White \\
\hline 13. & Color of seed (mature capsule) & Yellowish brown & Yellowish brown & Brownish & Brownish & Brownish \\
\hline
\end{tabular}

D. metel: Datura metel, D. innoxia: Datura innoxia

Table 3: Preliminary phytochemical screening of root and seed extracts of Datura spp.

\begin{tabular}{|c|c|c|c|c|c|c|c|c|c|c|c|c|}
\hline \multirow{2}{*}{$\begin{array}{l}\text { Test } \\
\text { compounds }\end{array}$} & \multicolumn{6}{|c|}{ Seeds } & \multicolumn{6}{|c|}{ Roots } \\
\hline & A & B & C & $\mathbf{E}$ & $\mathbf{H}$ & M & $\mathbf{A}$ & B & C & $\mathbf{E}$ & $\mathbf{H}$ & M \\
\hline Alkaloids & + & + & + & ++ & + & +++ & + & + & + & + & + & ++ \\
\hline Phenols & ++ & + & + & ++ & + & +++ & + & + & + & + & + & ++ \\
\hline Steroids & - & ++ & ++ & ++ & + & + & - & ++ & ++ & + & + & + \\
\hline Flavonoids & + & + & + & ++ & + & +++ & + & + & + & + & + & ++ \\
\hline Triterpenoids & + & + & + & ++ & + & +++ & + & + & + & + & + & ++ \\
\hline
\end{tabular}

+: Traces, ++: Present, +++: Strongly present, -: Absence. A: Aqueous,

B: Butanol, C: Chloroform, E: Ethyl acetate, H: Hexane, M: Methanol

the data regarding preliminary phytochemical screening of seed and root samples in the different solvent extract are given in Table 3. At present, the preliminary phytochemical screening of different extracts revealed that steroids were absent in the aqueous extracts of seeds and root samples. All the other compounds, namely alkaloids, phenols, steroids, flavonoids, and triterpenoids were present in all the root and seed samples screened but roots have a low level of these pharmaceutical compounds as compared to seeds.

\section{Total phenolic and flavonoids contents}

Polyphenols are one of the major groups of compounds that act as a primary antioxidant scavenger. The medicinal properties of the plant are due to the presence of polyphenols having various biological effects, so it is important to estimate the total phenolic content in the extracts of the plant. The data regarding total phenolic and flavonoids content in the seeds and roots in the different solvent extract were given in Table 4. The total phenolic content in the different solvent extracts of roots and seeds of D. metel (D1) ranges from $1.303 \pm 0.139$ to $6.533 \pm 0.135 \mathrm{mg} / \mathrm{g}$ dry weight (DW). The effect of different solvents on the extraction of phenolic content is clearly evident in the present study. In case of seed part, the order is $\mathrm{M}>\mathrm{E}>\mathrm{A}>\mathrm{C}>\mathrm{B}>\mathrm{H}$ and from root part, it is $\mathrm{M}>\mathrm{B}>\mathrm{E}>\mathrm{A}>\mathrm{C}>\mathrm{H}$. As maximum content is recorded in the methanolic extracts of seed parts, so methanol extracts of seeds of the different populations have been further analyzed. Among the different populations of Datura spp., maximum content was recorded in D4 and D5 samples $(10.39 \pm 0.174$ and $8.531 \pm 0.746 \mathrm{mg} / \mathrm{g}$ DW) Table 5 .

The total flavonoid content in the different solvent extracts of seeds and roots of D. metel (D1) ranges from $2.289 \pm 0.118$ to
$0.071 \pm 0.002 \mathrm{mg} / \mathrm{g}$ DW. The concentration trend of flavonoids content in different solvents of seed extracts with a decreasing order is $\mathrm{M}>\mathrm{E}>\mathrm{B}>\mathrm{H}>\mathrm{C}>\mathrm{A}$, while in roots is $\mathrm{E}>\mathrm{M}>\mathrm{H}>\mathrm{A}>\mathrm{C}>\mathrm{B}$. Interestingly from the root parts, flavonoid content is recorded in ethyl acetate solvent $(0.998 \pm 0.914 \mathrm{mg} / \mathrm{g} D W)$. The total flavonoids content is significantly high in seeds as compared to the roots (Table 4). Among the all samples studied of Datura flavonoid content with decreasing order are D1 $>$ D2 $>$ D3 $>$ D $5>$ D 4 Table 5 .

\section{Antioxidant assay}

Antioxidant activity was evaluated in terms of DPPH radical scavenging activity and TAC.

\section{TAC}

This assay is based on the formation of phosphate/Mo (V) complex in acidic medium by the reductive power of analyte. The method is quantitative, as the TAC is expressed as AA equivalents. TAC of seeds is more than roots as clearly seen in the given Table 6 . Aqueous and methanolic extracts have the maximum total antioxidant as compared with other solvents in seeds, while ethyl acetate and methanolic extracts in case of roots. In seeds of different accessions of Datura spp. D1 has the highest TAC $(10.35 \pm 0.217 \mathrm{mg} / \mathrm{g} \mathrm{DW})$ and D4 with the lowest $(7.041 \pm 0.091 \mathrm{mg} / \mathrm{g}$ DW) as shown in Table 7 .

\section{DPPH radical scavenging activity}

Different series of concentrations are tested to determine the concentration required to attain $50 \%$ radical scavenging effect $\left(\mathrm{IC}_{50}\right)$. Larger scavenging activity is indicated by the lower IC50 values, as lesser amount of extract is needed to decrease the concentration of DPPH to $50 \%$. The $\mathrm{IC}_{50}$ values of the different solvent extract are given in Tables 6 and 7. Methanol extract has higher DPPH radical scavenging activity as compared with the other solvents extracts in the present study. The decreasing order of activity in the seeds is $\mathrm{M}>\mathrm{E}>\mathrm{H}>\mathrm{A}>\mathrm{C}>\mathrm{B}$ and in the roots is $M>E>A>H>B>C$ (Table 6). Between the various accessions of Datura, D1 has the highest value of activity and the lowest in D2 and D3 Table 7.

HPTLC analysis of chlorogenic acid and caffeic acid

HPTLC has emerged as an important tool for quantitative and qualitative analysis of different phytochemicals from herbal drug formulations. Analysis of different marker compounds has been done by various workers in different plant species by this technique which is best suitable for identification, visualization, and quantification 
Table 4: The content of total phenol and flavonoids in the different solvent extracts of seeds and roots of D1

\begin{tabular}{|c|c|c|c|c|c|}
\hline \multirow[t]{2}{*}{ S. No. } & \multirow{2}{*}{$\begin{array}{l}\text { Extracts } \\
\text { Solvents }\end{array}$} & \multicolumn{2}{|c|}{$\begin{array}{l}\text { TPC(mg chlorogenic acid equivalent/g } \\
\text { dry weight) }\end{array}$} & \multicolumn{2}{|c|}{$\begin{array}{l}\text { TFC (mg quercetin equivalent/g dry } \\
\text { weight) }\end{array}$} \\
\hline & & Seeds & Roots & Seeds & Roots \\
\hline 1. & Aqueous & $3.756 \pm 0.073$ & $1.983 \pm 0.126$ & $0.914 \pm 0.046$ & $0.090 \pm 0.002$ \\
\hline 2. & Butanol & $2.578 \pm 0.149$ & $2.308 \pm 0.056$ & $1.182 \pm 0.021$ & $0.071 \pm 0.002$ \\
\hline 3. & Chloroform & $3.111 \pm 0.073$ & $1.581 \pm 0.169$ & $0.926 \pm 0.047$ & $0.080 \pm 0.003$ \\
\hline 4. & Ethyl acetate & $4.156 \pm 0.713$ & $2.039 \pm 0.146$ & $1.824 \pm 0.042$ & $0.998 \pm 0.041$ \\
\hline 5. & Hexane & $2.189 \pm 0.179$ & $1.303 \pm 0.139$ & $1.152 \pm 0.037$ & $0.424 \pm 0.024$ \\
\hline 6. & Methanol & $6.533 \pm 0.135$ & $6.511 \pm 0.106$ & $2.289 \pm 0.117$ & $0.906 \pm 0.021$ \\
\hline
\end{tabular}

Values are mean \pm standard error of three replicates. TPC: Total phenolic content, TFC: Total flavonoid content

Table 5: The content of total phenol and flavonoids in the methanolic extracts of seeds of different accessions of Datura spp

\begin{tabular}{llll}
\hline S. No. & Samples & $\begin{array}{l}\text { TPC (mg chlorogenic acid } \\
\text { equivalent/g dry weight) }\end{array}$ & $\begin{array}{l}\text { TFC (mg quercetin } \\
\text { equivalent/g dry weight) }\end{array}$ \\
\hline 1. & D1 & $6.533 \pm 0.135$ & $2.289 \pm 0.118$ \\
2. & D2 & $3.983 \pm 0.236$ & $2.046 \pm 0.101$ \\
3. & D3 & $3.894 \pm 0.159$ & $1.722 \pm 0.055$ \\
4. & D4 & $10.39 \pm 0.174$ & $1.534 \pm 0.013$ \\
5. & D5 & $8.531 \pm 0.746$ & $1.668 \pm 0.046$ \\
\hline
\end{tabular}

Values are Mean \pm Standard error of three replicates. TPC: Total phenolic content, TFC: Total flavonoid content

Table 6: Total antioxidant capacity and DPPH radical scavenging activity of different solvent extracts of seeds and roots of D1

\begin{tabular}{|c|c|c|c|c|c|}
\hline \multirow[t]{2}{*}{ S. No. } & \multirow[t]{2}{*}{ Solvents } & \multicolumn{2}{|c|}{ TAC (mg AA equivalent/gm dry wt) } & \multicolumn{2}{|c|}{ DPPH ( $\left.\mathrm{IC}_{50} \mu \mathrm{g} / \mathrm{ml}\right)$} \\
\hline & & Seeds (D1) & Roots (D1) & Seeds (D1) & Roots (D1) \\
\hline 1. & Aqueous & $10.21 \pm 0.217$ & $3.928 \pm 0.033$ & 16.075 & 39.487 \\
\hline 3. & Chloroform & $6.528 \pm 0.035$ & $3.272 \pm 0.021$ & 21.5 & 110 \\
\hline 4. & Ethyl acetate & $7.82 \pm 0.091$ & $4.316 \pm 0.028$ & 12.740 & 32.083 \\
\hline 5. & Hexane & $8.655 \pm 0.165$ & $3.704 \pm 0.023$ & 13.651 & 59.231 \\
\hline 6. & Methanol & $10.35 \pm 0.217$ & $4.759 \pm 0.089$ & 10.886 & 16.559 \\
\hline
\end{tabular}

Values are mean \pm standard error of three replicates. DPPH: 2, 2-Diphenyl-1-picrylhydrazyl, TAC: Total antioxidant capacity

Table 7: Total antioxidant capacity and DPPH radical scavenging activity of seeds of different accessions of Datura spp.

\begin{tabular}{llll}
\hline S. No. & Samples & $\begin{array}{l}\text { TAC } \\
\text { (mg AA equivalent/gm dry } \mathbf{w t})\end{array}$ & $\begin{array}{l}\text { DPPH } \\
\left.\text { ( IC }_{\mathbf{5 0}} \boldsymbol{\mu g} / \mathbf{m l}\right)\end{array}$ \\
\hline 1. & D1 & $10.35 \pm 0.217$ & 10.886 \\
2. & D2 & $7.757 \pm 0.113$ & 21.536 \\
3. & D3 & $8.441 \pm 0.088$ & 20.601 \\
4. & D4 & $7.041 \pm 0.091$ & 12.286 \\
5. & D5 & $9.293 \pm 0.126$ & 15.177 \\
\hline
\end{tabular}

Values are Mean \pm Standard error of three replicates. DPPH: 2

2-Diphenyl-1-picrylhydrazyl, TAC: Total antioxidant capacity

of biologically active compounds. Datura is rich in biologically active compounds; hence, pharmacologically important two marker compounds chlorogenic acid and caffeic acid have been identified and quantified by HPTLC technique.

The bands are visualized at $366 \mathrm{~nm}$ under UV light (Fig. 2). The confirmation of the $\mathrm{R}_{\mathrm{f}}$ values of chlorogenic acid and caffeic acid is found to be 0.15 and 0.80 , respectively (Table 8 ). HPTLC densitometric chromatogram of standard tracks and sample tracks is given in Fig. 3. Both standard compounds are found to be linear over the range of 200-600 ng/spot. The linear regression equations with correlation coefficient values for both compounds are given in Table 8. The content of phenolic compounds in plant samples has been measured using a calibration curve of the standard compounds.

Out of six solvents used for extraction in roots, the maximum amount of caffeic acid was observed in butanol crude extracts, while in case of seeds

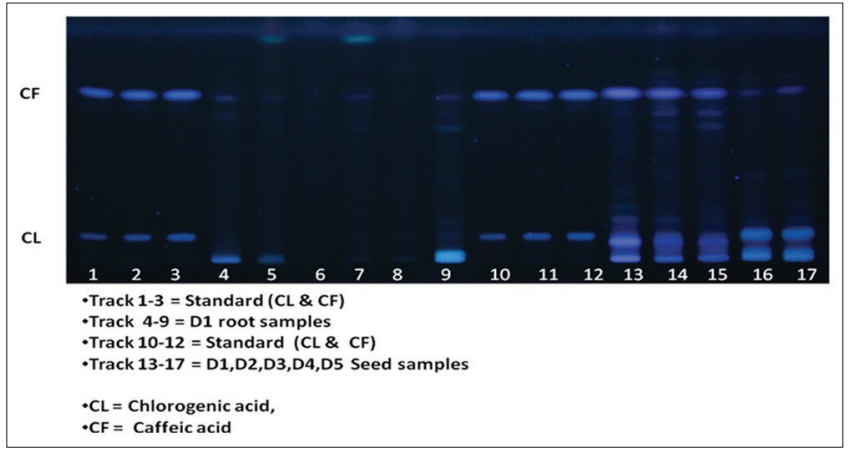

Fig. 2: High-performance thin-layer chromatography chromatogram at $366 \mathrm{~nm}$

of all studied populations of Datura, maximum content was observed in D1. Chlorogenic acid was not detected from the root parts in the present study shown in Fig. 2. Maximum amount was detected in the D5 and D4 population of $D$. innoxia. Between the two species studied, $D$. metel is rich in caffeic acid and D. innoxia is rich in chlorogenic acid. This is the first report of the detection and quantification of these two hydroxycinnamic acids from the root and seed parts of Datura spp. shown in Graph 1.

\section{DISCUSSION}

Since the Vedic period there were descriptions on medicinally important plants and their identification, distribution and therapeutical properties for various ailments [14]. Nowadays, people are enthusiastically interested in the study of medicinal plants for different biologically 
Table 8: Different parameters of the HPTLC method

\begin{tabular}{llllll}
\hline S. No. & Marker compounds & Linearity range (ng) & Linear equation & Retention factor (Rf) & Correlation coefficient \\
\hline 1. & Caffeic acid & $200-600$ & $\mathrm{y}=18.9 \mathrm{x}-1503$ & 0.15 & $>0.990$ \\
2. & Chlorogenic acid & $200-600$ & $\mathrm{y}=7.21 \mathrm{x}+430$ & 0.80 & $>0.997$ \\
\hline
\end{tabular}

HPTLC: High-performance thin-layer chromatography

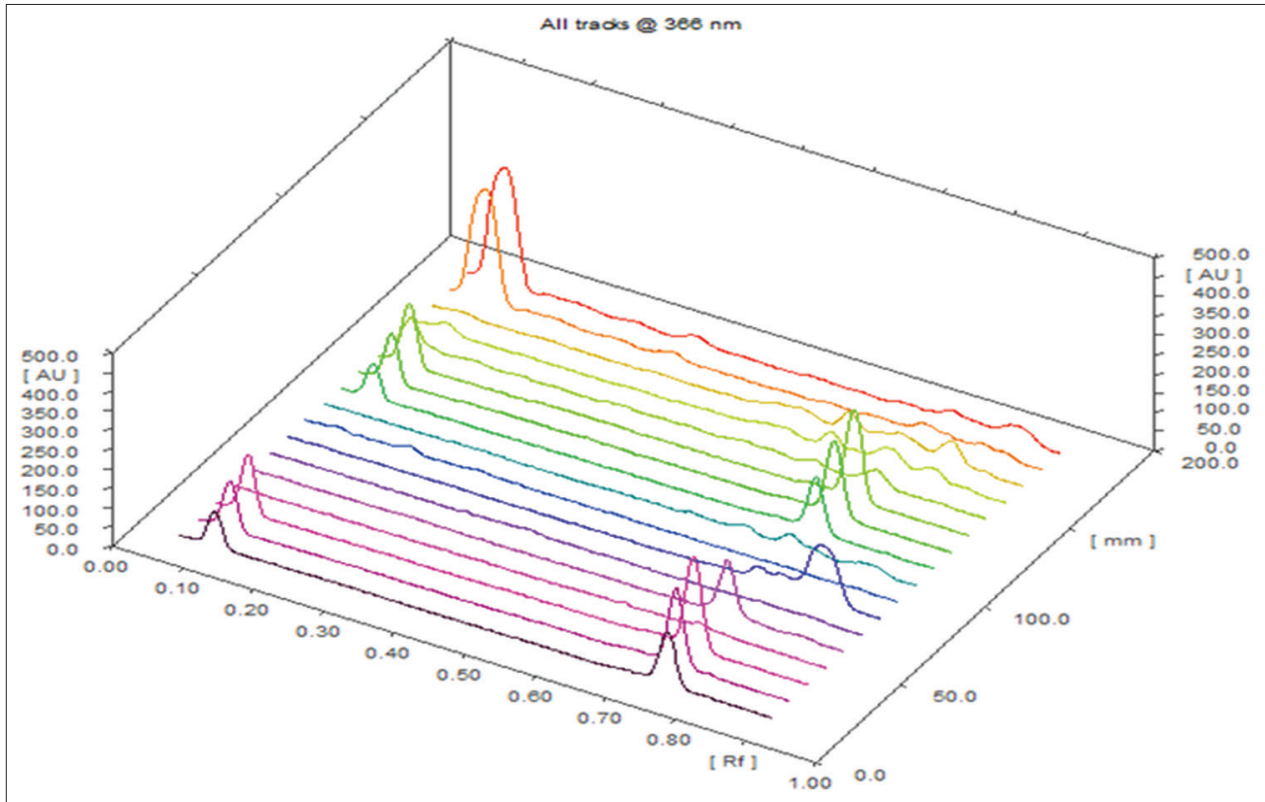

Fig. 3: Three-dimensional chromatogram of tracks

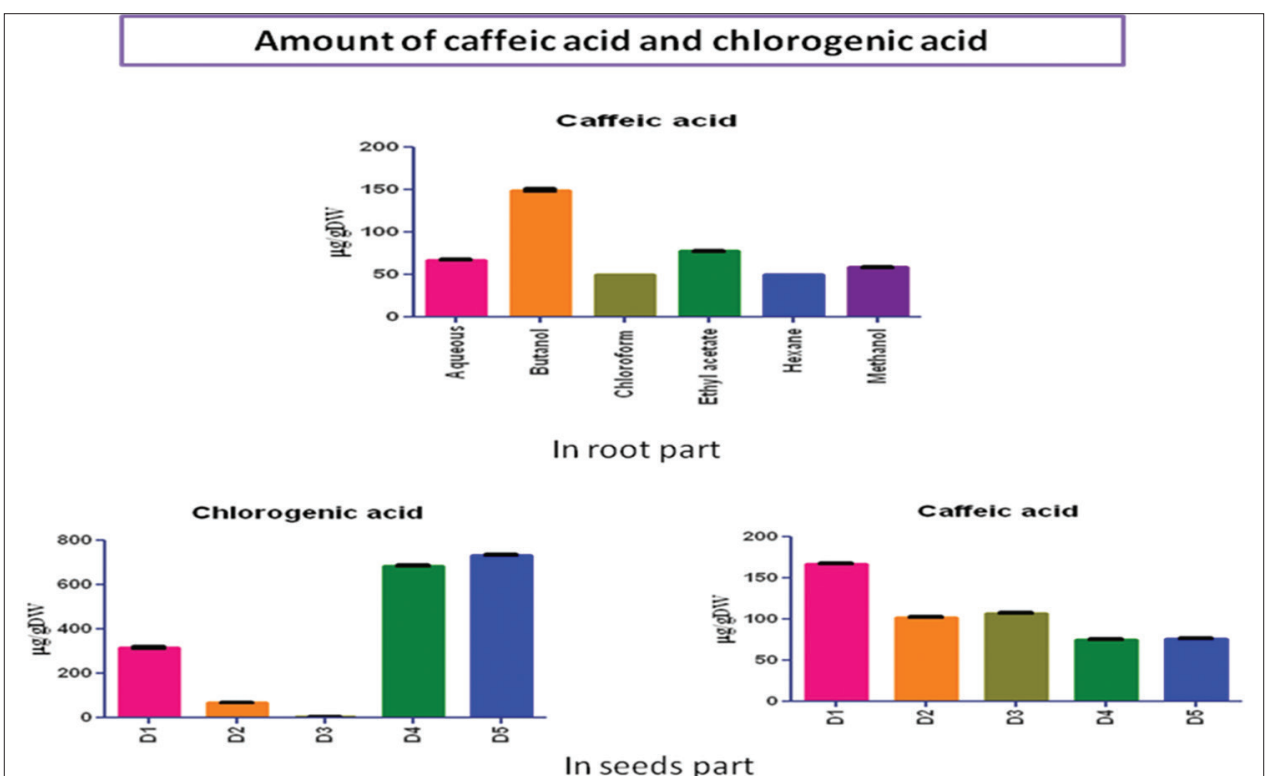

Graph 1: (a-c) Content of caffeic acid and chlorogenic acid in the roots and seeds ( $\mu \mathrm{g} / \mathrm{g}$ DWE) of different populations of Datura metel and Datura innoxia

active phytoconstituents which exhibit important therapeutic effects. During the present study, the collections of Datura species are made from Punjab for evaluation of phytochemical diversity. In the results, two morphotypes (D1 and D2) have been recorded within the same species of $D$. metel. On morphological comparison, a lot of variation has been recorded between two morphotypes of $D$. metel and in between species. On the basis of morphological comparisons, morphotype D1 had triple whorled corolla; yellowish with purplish margin flower, and broad leaves, while in case of morphotype (D2) has a single whorled corolla, white inside and purple outside flower and comparatively small leaves.
Similarly, morphological diversity and hyoscyamine/scopolamine contents in 12 Algerian samples of D. stramonium of different origin were previously reported [15]. Phytochemical constituents in the plant samples are known to be biologically active compounds, and they are responsible for different activities such as antioxidant, antimicrobial, antifungal, and anticancer [16,17]. All secondary metabolite components displayed antioxidant and antimicrobial properties through different biological mechanisms. Most of the secondary metabolite components were isolated and identified in the polar plant crude extracts [18]. In the present study, most of the bioactive 
compounds were found in polar methanol and ethyl acetate crude extracts of seeds and roots. Further, during preliminary screening, it was observed that seeds have good amount of phytoconstituents as compared to roots. Jamdhade et al. had done a qualitative analysis of the extracts from the root, stem, leaf, seed, and fruit coat sample of D. metel and showed that leaf and roots contain more alkaloids, tannins, saponins, and iridoids [19]. The content of phenols and flavonoids is greatly influenced by the type of extraction solvent and parts of the plant, as is very much clear in the present results. Phenols and flavonoids are highly beneficial for human health for combating several diseases, as these have a high effect on the scavenging of singlet oxygen and free radicals [20-23]. The present observations are in accordance with the findings of different workers and our results also suggest that these polyphenols profoundly contribute to the antioxidant potential of Datura spp. [24].

Antioxidant activity was evaluated in terms of DPPH radical scavenging activity and TAC. DPPH radical is widely used to check the antioxidant potential of medicinal plants due to its high sensibility and easily availability. The crude extract of D. metel and D. innoxia contain flavonoid, steroids, alkaloids, phenolic, and triterpenoids. All these bioactive compounds are able to discolor DPPH solution by their hydrogen donating ability $[25,26]$. D. stramonium seeds possess alkaloids and flavonoids and have potent antioxidant and antibacterial activities [27]. The antioxidant activity through free radical scavenging activity (DPPH) method showed that seeds have maximum activity as compared to root parts. So far, between the seed samples of different Datura spp. studied, D1 has maximum activity of radical scavenging and antioxidant capacity, due to the presence of more flavonoids. Several reports are available on flavonoid groups which exhibited high potential biological activities such as antioxidant, anti-inflammatory, antimicrobial, antiangiogenic, anticancer, and anti-allergic reactions [28-32].

HPTLC is a unique technique which can be applied for simultaneous identification of different compounds in the same plant or the specific compounds in different plants in a single attempt. This method is highly economic time saving, needs less expertise, needs a small amount of solvent, and screens a huge number of samples simultaneously. This method can be applied for the qualitative and quantitative determination of various phytoconstituents in medicinal plants. The specific fingerprints of species are developed through HPTLC and can be used to check adulteration at any stage.

In the present study, HPTLC densitogram analysis has been used for quantification of specific pharmacologically important compounds in the seed and root part of D. metel and D. innoxia. As the morphological study reveals two morphotypes of D. metel, i.e., D1 and D2 have been subjected to the qualitative as well as quantitative determination of phytoconstituents. An HPTLC densitometric method for the quantification of these biomarker compounds in various plant species has been developed by many workers [33-38]. Rahmoune et al. have investigated phenylpropanoids and fatty acids composition in leaves and roots extracted from $D$. innoxia and D. stramonium using gas chromatography-electron impact/time of flight mass spectrometry (GC-EI/TOF-MS) chromatography techniques. They revealed that in both the Datura species, phenylpropanoids composition in leaves was remarkably higher than in the roots. However; fatty acids (hexadecanoic acid and octadecanoic acid) are observed in almost equal rate between leaves and roots [39]. To the best of our knowledge, the present investigation is the first report of the detection and quantification of these two hydroxycinnamic acids (chlorogenic and caffeic acid) from the root and seed parts of Datura spp.

\section{CONCLUSION}

The present study depicts that there is a lot of variability in terms of morphology and phytoconstituents among the different species and populations of Datura. The presence of such diversity in the quantities of active compounds in different morphotypes or populations, establish the necessities of phytochemical screening covering various ecotypes/ morpho/cytotypes. Further, these marked chemotypes should be standardized for medicinal dose and authentication of products for the international market.

\section{ACKNOWLEDGMENT}

The authors are grateful to the Department of Botany and Sophisticated Instrumentation Centre, Punjabi University, Patiala, Punjab, India, for providing necessary facilities to carry out HPTLC analysis. The corresponding author is highly thankful to the DBT-IPLS (Ref. No.BT/ PR 4548/NF/22/146/2012) for providing Senior Research Fellowship.

\section{AUTHORS' CONTRIBUTION}

The concept and design of the study were done by Dr. RC Gupta and Mr. Saroj Kumar Pradhan. Experimental work was done by Mr. Mahinder Partap. Interpretation of data and draft of manuscript were prepared by Mr. Mahinder Partap and Mr. Saroj Kumar Pradhan. Revision of article and proofreading was done by Dr. RC Gupta.

\section{CONFLICTS OF INTEREST}

The authors declared no conflicts of interest.

\section{REFERENCES}

1. Dorman HJ, Deans SG. Antimicrobial agents from plants: Antibacterial activity of plant volatile oils. J Appl Microbiol 2002;88:308-16.

2. Preissel U, Preissel HG. Brugmansia and Datura: Angel's Trumpets and Thorn Apples. Buffalo, New York: Firefly Books; 2002. p. 106-29.

3. Dogra KS, Kohli RK, Sood SK. An assessment and impact of three invasive species in the Shivalik hills of Himachal Pradesh, India. Int J Biodivers Conserv 2009;1:4-10.

4. Nandini D, Ravikumar BS, Rashmi KK. Morphometric analysis of Datura plant to understand variation and similarities among four major species. Med Aromat Plants 2015;4:4.

5. Harbourne JB. Phytochemical Methods: A Guide to Modern Techniques of Plant Analysis. London: Chapman and Hall Ltd.; 1973. p. 279.

6. Okwu DE. Phytochemical and vitamin content of indigenous spices of South Eastern Nigeria. J Sustain Agric Environ 2004;6:30-34.

7. Boerjan W, Ralph J, Baucher M. Lignin biosynthesis. Annu Rev Plant Biol 2003;54:519-46.

8. Olthof MR, Hollman PC, Katan MB. Chlorogenic acid and caffeic acid are absorbed in humans. J Nutr 2001;131:66-71.

9. Slinkard K, Singleton VL. Total phenol analyses: Automation and comparison with manual methods. Am J Enol Vitic 1977;28:49-55.

10. Saeed N, Khan MR, Shabbir M. Antioxidant activity, total phenolic and total flavonoid contents of whole plant extracts Torilis leptophylla $\mathrm{L}$. BMC Complement Altern Med 2012;12:221.

11. Prieto P, Pineda M, Aguilar M. Spectrophotometric quantitation of antioxidant capacity through the formation of a phosphomolybdenum complex: Specific application to the determination of Vitamin E. Anal Biochem 1999;269:337-41

12. Otang WM, Grierson DS, Ndip RN. Antifungal activity of Arctotis arctotoides (L.f.) O. Hoffm. and Gasteria bicolor Haw. Against opportunistic fungi associated with HIV/AIDS. Pharmacog Mag 2012;30:135-40.

13. Pradhan SK, Gupta RC, Goel R, Preet R. Simultaneous determination of chlorogenic and caffeic acid in Siegesbeckia orientalis L. (Xi Xian) by a validated high-performance thin-layer chromatographic method. J Planar Chromatogr 2017;30:516-20.

14. Joy PP, Thomas J, Mathew S, Skaria, B.P. Medicinal Plants. Tropical Horticulture vol. 2. (eds. Bose, T.K., Kabir, J., Das, P. and Joy, P.P.). Naya Prokash, Calcutta 2001: 449-632.

15. Abdelkader M, Arezki D, Khelifi-Slaoui's M, Khelifi L, Amdoun R, Bakiris N. Morphological diversity and hyoscyamine/scopolamine contents in twelve Algerian samples of Datura stramonium L. of different origin. Rev Ecol 2011;66:291-302.

16. Hossain MA, Nagooru MR. Biochemical profiling and total flavonoids contents of leaves crude extract of endemic medicinal plant Corydyline terminalis L. Kunth. Pharmacogn J 2011;3:25-9.

17. Suresh SN, Nagarajan N. Preliminary phytochemical and antimicrobial activity analysis of Begonia malabarica Lam. J Basic Appl Biol 2009;3:59-61.

18. Gonzalez-Guevara JL, Gonzalez-Lavaut JA, Pino-Rodriguez S, 
Garcia-Torres M, Carballo-Gonzalez MT, Echemendia-Arana OA, et al. Phytochemical screening and in-vitro antiherpetic activity of four Erythtroxylum species. Acta Farm Bonaer 2004;23:506-9.

19. Jamdhade MS, Survase SA, Kare MA, Bhuktar AS. Phytochemical studies on Datura metel L.in Marathwada region, Maharashtra. J Phytol 2010;2:46-8

20. Mahomoodally MF, Gurib-Fakim A, Subratty AH. Antimicrobial activities and phytochemical profiles of endemic medicinal plants of Mauritius. Pharm Biol 2008;43:237-42.

21. Gulcin I, Haci AA, Cesur M. Determination of in-vitro antioxidant and radical scavenging activities of propofol. Chem Pharm Bull 2005;53:281-5.

22. Barile E, Bonanomi G, Antignani V, Zolfaghari B, Ebrahim SS, Scala F, et al. Phytochemical screening and antimicrobial assessment of Abutilon mauritianum, Bacopa monifera and Datura stramonium. Phytochemistry 2007;68:596-603.

23. Ayoola GA, Coker HA, Adesegun SA, Adepoju-Bello AA, Obaweya K, Ezennia EC, et al. Phytochemical screening and antioxidant activities of some selected medicinal plants used for malaria therapy in South Western Nigeria. Trop J Pharm Res 2008;7:1019-24.

24. Akharaiyi FC. Antibacterial, phytochemical and antioxidant activities of Datura metel. Int J Pharm Tech Res 2011;3:478-83.

25. Varahalarao V, Kaladhar DS. Antimicrobial study of plant extracts of Datura metel L. against some important disease causing pathogens. Asian Pac J Trop Dis 2012;2:94-9.

26. Sekar D, Kolanjinathan K, Saranraj P, Gajendiran K. Screening of Phyllanthus amarus, Acalypha indica and Datura metel for its antimicrobial activity against selected pathogens. Int J Pharm Biol Sci Arch 2012;3:1231-5.

27. Waza SA, Anthony P, Dar S. Phytochemical analysis, antioxidant and antimicrobial activities of methanolic extract of Datura stramonium seeds. Int J Pharm Sci Res 2015;6:3021-6.

28. Anyasor GN, Ogunwenmo KO, Oyelana OA, Akpofunure BE. Phytochemical constituents and antioxidant activities of aqueous and methanol stem extracts of Costus afer Ker Gawl. (Costaceae). Afr J Biotechnol 2010;9:4880-4.
29. Chao PD, Hsiu SL, Hou YC. Flavonoids in herbs: Biological fates and potential interactions with xenobiotics. J Food Drug Anal 2002;10:219-28.

30. Igbinosa OO, Igbinosa EO, Aiyegoro OA. Antimicrobial activity and phytochemical screening of stem bark extracts from Jatropha curcas (Linn). Afr J Pharm Pharmacol 2009;3:58-62.

31. Thitilertdecha N, Teerawutgulrag A, Rakariyatham N. Antioxidant and antibacterial activities of Nephelium lappaceum L. extracts. Food Sci Technol 2008;41:2029-35.

32. Hollman PC, Katan MB. Dietry flavonoids: Intake, health effects and bioavailability. Food Chem Toxicol 1999;37:937-42.

33. Chidambaram V, Niraimathi L, Sudha V, Lavanya R, Vadivel V, Brindha P. Spectrophotometric, HPTLC and GC-MS studies on selected spice extracts. Int J Pharm Pharm Sci 2015;7:184-90.

34. Jaafar NS, Hamad MN, Abbas IS, Jaafar IS. Qualitative phytochemical comparison between flavonoids and phenolic acids contents of leaves and fruits of Melia azedarach (family: Meliaceae) cultivated in Iraq by HPLC and HPTLC. Int J Pharm Pharm Sci 2016;8:242-50.

35. Usman MR, Surekha S, Rashmi S, Lalit S, Kumar N, Gadgoli J, et al. High performance thin layer chromatograpic method for quantification of $\beta$-sitosterol from Vanda roxburghii R.Br. Asian J Plant Sci Res 2012;4:113-24

36. Pradhan SK, Gupta RC, Goel R. Differential content of secondary metabolites in diploid and tetraploid cytotypes of Siegesbeckia orientalis L. Nat Prod Res 2018;15:1-7.

37. Gopal V, Mandal SC. HPTLC evaluation of oleanolic acid and ursolic acid from the methanol extract of Wattakaka volubils. J Acute Dis 2014;5:59-61.

38. Hussain MS, Fareed S, Ali M, Alam MS, Rahman MA, Srivastava AK. Phytochemical investigation and simultaneous estimation of bioactive lupeol and stigmasterol in Abutilon indicum by validation HPTLC method. J Coast Life Med 2014;2:394-401.

39. Rahmoune B, Zakarya I, Morsli A1, Khelifi-slaoui M, Khelifi L, Do amarante L. Phenylpropanoids and fatty acids levels in roots and leaves of Datura stramonium and Datura innoxia. Int J Pharm Pharm Sci 2017;9:150-4 